\section{Does leisure-time physical activity in early adulthood predict later physical activity? Pro-Saude Study}

\section{Atividade física de lazer no início da vida adulta prediz a atividade física posterior? Estudo Pró-Saúde}

\section{Danielle Nogueira ${ }^{1,2}$ \\ Eduardo Faerstein ${ }^{1}$ \\ Inês Rugani ${ }^{3}$ \\ Dora Chor ${ }^{4}$ \\ Claudia S. Lopes ${ }^{1}$ \\ Guilherme L. Werneck ${ }^{5}$}

${ }^{1}$ Departamento de Epidemiologia do Instituto de Medicina Social da Universidade do Estado do Rio de Janeiro

${ }^{2}$ Divisão de Informação do Instituto Nacional de Câncer (INCA)

${ }^{3}$ Instituto de Nutrição Annes Dias da Secretaria Municipal de Saúde do Rio de Janeiro

${ }^{4}$ Departamento de Epidemiologia e Métodos Quantitativos em Saúde da Escola Nacional de Saúde Pública da Fundação Oswaldo Cruz

${ }^{5}$ Departamento de Epidemiologia e Bioestatística do Instituto de Estudos em Saúde Coletiva da Universidade Federal do Rio de Janeiro

Este trabalho foi financiado pela Fundação Carlos Chagas Filho de Amparo à Pesquisa do Estado do Rio de Janeiro (FAPERJ), Processo N ${ }^{\circ}$ E-26/110-315/2007.

Correspondência: Danielle Nogueira. Rua dos Inválidos, 212 - $3^{\circ}$ andar Centro - Rio de Janeiro, RJ CEP: 20231-048. E-mail: dramos@inca.gov.br

\section{Resumo}

Introdução: Atividade física é um comportamento de saúde relativamente estável, em geral determinado no início da vida adulta. Atividade física de lazer (AFL) é um dos poucos comportamentos benéficos à saúde mais prevalente entre homens que entre mulheres. Métodos: Foram analisados dados de 3.199 participantes do Estudo Pró-Saúde - coorte de funcionários de universidade no Rio de Janeiro, coletados por meio de questionário multidimensional e autopreenchível. A associação entre AFL no início da vida adulta e posteriormente foi analisada com uso de regressão logística multinomial, com estimativas de razões de chance (odds ratio) e seus respectivos intervalos de $95 \%$ de confiança considerando três categorias de desfecho: sedentários, insuficientemente ativos e ativos. AFL pregressa foi agrupada em 3 categorias: nunca/raramente (categoria de referência), às vezes, quase sempre/sempre. Estimativas foram ajustadas por idade, escolaridade, escolaridade dos pais e cor/raça. Resultados: Homens que se engajavam em AFL às vezes e quase sempre/sempre no início da vida adulta tiveram, respectivamente, $\mathrm{OR}$ $=1,42$ (IC 95\%: 0,70-2,89) e OR = 3,33 (IC 95\%: 1,82-6,10) de ser fisicamente ativos em idade posterior do que os sedentários. Entre as mulheres, os odds ratios foram menores: $\mathrm{OR}=1,19$ (IC 95\%: 0,79-1,79) e OR =1,42 (IC 95\%: 1,00-2,04). Conclusão: A prática de AFL durante o início da vida adulta apresentou associação com atividade física posterior, e essa associação foi mais expressiva em homens do que em mulheres. Políticas públicas que encorajem a AFL entre os jovens, com esforços específicos direcionados às mulheres, poderiam aumentar a proporção de adultos fisicamente ativos.

Palavras-chave: Atividade física de lazer. Equivalente metabólico. Gênero. Curso de vida. 


\section{Abstract}

Introduction: Leisure-Time Physical Activity (LTPA) is a health behavior that is considered relatively stable over the course of life; this life-long habit seems to be shaped during youth and early adulthood. LTPA is one of the few healthy behaviors more prevalent among men than among women. Methods: Data from 3,199 participants of the Pro-Saude Study were analyzed - a cohort of employees of a university in Rio de Janeiro, collected with a self-reported multidimensional questionnaire. The association between LTPA in early adulthood and later was investigated using multinomial logistic regression, with estimated odds ratios (OR), considering three outcome categories: inactive, insufficiently active, and active. Past LTPA was grouped into three categories: never/rarely (reference category), sometimes and frequently/always. Estimates were adjusted for: age; participants` schooling, their father's and mother's schooling, and color/race. Results: Analysis shows men who engaged in LTPA sometimes and almost always/always in early adulthood had an $\mathbf{O R}=1.42(95 \%$ CI: 0.70-2.89) and $\mathbf{O R}=3.33$ (95\% CI: 1.82-6.10), respectively, of being physically active in later adulthood than those who did not engage in LTPA. Among women, the corresponding odds ratios were lower: OR = 1.19 (95\% CI: 0.79-1.79) and OR $=1.42$ (95\% CI: 1.00-2.04). Conclusion: LTPA during early adulthood is associated with physical activity later in adulthood, and this association is stronger in men than in women. Public policies that encourage LTPA among youth, with specific efforts directed at women, could increase the proportion of physically active adults.

Keywords: Leisure-time physical activity. Metabolic equivalent. Gender. Life course.
Introduction

Leisure-time physical activity (LTPA) is considered a good proxy for general levels of physical activity of a population ${ }^{1}$. Leisure time inactivity is one of the strongest predictors of premature morbidity and mortality ${ }^{2}$, and is associated with the global obesity pandemic ${ }^{3}$.

Physical activity is a health behavior that is considered relatively stable over the course of life ${ }^{4}$, but this life-long habit seems to be shaped during youth and early adulthood $^{5}$. These years, however, are also characterized by important changes-entry into the job market, marriage and the birth of children-which are often accompanied by reductions in physical activity ${ }^{6}$.

LTPA is one of the few healthy behaviors which are more prevalent among men than among women ${ }^{7}$. Women are generally believed to engage less in regular physical activities, in vigorous exercise and in sports, but there are relatively few reports ${ }^{8,9}$ examining gender differences in the practice and sustainability of physical activity in the scientific literature. Psychosocial, environmental, and biologic ${ }^{10}$ factors have been postulated to explain some of these inequalities.

This study investigated whether there are gender differences in levels of LPTA in early adulthood and later among university employees in Rio de Janeiro, Brazil.

\section{Methods}

This study analyzed data from participants of a longitudinal cohort study (ProSaude Study) with non-faculty civil servants of a university in Rio de Janeiro, Brazil. Data were collected in 1999 and 2001. All 4,177 eligible employees were invited to participate; the response rate was $78.2 \%(3,253)$. Analyses presented here are based on 3,199 individuals (56\% women) with complete data for the variables studied.

Both data collection phases of the Pro-Saude Study used a self-reported multidimensional questionnaire. LTPA in early adulthood was assessed by asking re- 
spondents to recall: "From 18 to 22 years of age, how often, on average, did you practice some intensive physical activity or sport (for example, cycling, swimming, volleyball, soccer, running, or other)?" Possible answers included: never, rarely, sometimes, almost always, always.

To assess current LTPA, respondents were asked to quantify physical activity undertaken in the prior 15 days, taking into account the intensity, average duration (in minutes per session), and weekly frequency. From responses we generated a measure of the Weekly Metabolic Expenditure (WME). WME was calculated by multiplying energy spent in each activity ${ }^{11}$, expressed in Metabolic Equivalents (MET), by the average duration of each activity; this product was in turn multiplied by the number of sessions per week. MET is the unit of measure used to estimate energy spent (expressed in terms of $\mathrm{O}_{2}$ consumed) with a given physical activity and is widely used in epidemiologic studies $^{12,13}$.

Participants who reported no LTPA were classified as inactive. In order to classify levels of LTPA we used a cut-off point of 600 $\mathrm{MET}^{14}$, which corresponds to 30 minutes of moderate physical activity five times per week as recommended by the Centers for Disease Control and Prevention of the United States of America and the American College of Sports Medicine ${ }^{15}$. Individuals who practiced LTPA were classified as insufficiently active (WME $<600$ MET-min/ week) or active (WME $\geq 600 \mathrm{MET}-\mathrm{min} /$ week).

The association between LTPA in earlier and later adulthood was investigated using multinomial logistic regression, with estimated odds ratios (OR) and their respective 95\% confidence intervals, considering three outcome categories: inactive, insufficiently active, and active. Past LTPA were grouped into three categories: never/rarely (reference category), sometimes and frequently/ always. Estimates were adjusted for: age (in years); participants' schooling and their father's and mother's schooling (incomplete high school, complete high school, college graduate) and color/race (white, brown, black). All analyses were stratified according to gender. Data analyses were performed using STATA software, version 8.0.

The research protocol was approved by the institutional ethics committee. Informed written consent was obtained from all participants.

\section{Results}

Our study population was on average aged $43( \pm 7.9)$ years; approximately $43 \%$ had college education, and $51 \%$ described themselves as white. About $10 \%$ of men and $50 \%$ of women reported never/rarely LTPA practice from 18 to 22 years of age. Approximately $61 \%$ of the participants were inactive (55.4\% men and $66.5 \%$ women) at the time of the study (Table 1).

Table 2 presents crude and adjusted odds ratios from the multinomial logistic regression. Figure 1 shows that men who engaged in LTPA sometimes and almost always/always in early adulthood were 1.42 (95\% CI: 0.70-2.89) and 3.33 (95\% CI: 1.826.10) times more likely, respectively, to be physically active in later adulthood than those who did not practice LTPA. Among women, corresponding odds ratios were lower: $\mathrm{OR}=1.19$ (95\% CI: 0.79-1.79) and OR $=1.42$ (95\% CI: 1.00-2.04).

\section{Discussion}

To our knowledge, this is the first study to examine gender differences in the association of early and later adulthood LTPA in a developing country, where obesity is becoming a public health problem.

In the study population, regular participation in intense physical activities and/ or sports in young adulthood increased the likelihood that an individual would remain active in later adulthood. These chances were statistically higher among men.

Physical activity in adolescence is positively associated with higher levels of physical activity in adult life ${ }^{16}$. Most studies on these themes have been conducted in North Ame- 
Table 1 - Characteristics of the population, Pro-Saude Study, 1999-2001

Tabela 1 - Características da população, Estudo Pró-Saúde, 1999-2001.

\begin{tabular}{|c|c|c|c|c|}
\hline & \multicolumn{2}{|c|}{ Men } & \multicolumn{2}{|c|}{ Women } \\
\hline & $\mathbf{N}$ & $\%$ & $\mathbf{N}$ & $\%$ \\
\hline \multicolumn{5}{|l|}{ Age (years) } \\
\hline $30-34$ & 216 & 16.3 & 214 & 12.4 \\
\hline $35-44$ & 635 & 47.9 & 809 & 46.8 \\
\hline $45-54$ & 377 & 28.4 & 544 & 31.5 \\
\hline $55-64$ & 83 & 6.3 & 145 & 8.4 \\
\hline 65 or more & 14 & 1.1 & 16 & 0.9 \\
\hline \multicolumn{5}{|l|}{ Schooling } \\
\hline Incomplete high school & 431 & 30.3 & 348 & 18.7 \\
\hline Complete High school & 515 & 36.2 & 623 & 33.5 \\
\hline College or more & 476 & 33.5 & 889 & 47.8 \\
\hline \multicolumn{5}{|l|}{ Father's schooling } \\
\hline Incomplete high school & 566 & 42.4 & 745 & 44.4 \\
\hline Complete High school & 359 & 26.9 & 425 & 25.4 \\
\hline College or more & 410 & 30.7 & 506 & 30.2 \\
\hline \multicolumn{5}{|l|}{ Mother's schooling } \\
\hline Incomplete high school & 719 & 51.7 & 953 & 54.4 \\
\hline Complete High school & 369 & 26.5 & 436 & 24.9 \\
\hline College or more & 304 & 21.8 & 364 & 20.8 \\
\hline \multicolumn{5}{|l|}{ Color/race } \\
\hline White & 653 & 50.4 & 861 & 50.3 \\
\hline Brown & 430 & 33.1 & 501 & 29.2 \\
\hline Black & 176 & 13.6 & 305 & 17.8 \\
\hline Others (Asians, Indian) & 38 & 2.9 & 47 & 2.7 \\
\hline \multicolumn{5}{|c|}{$\begin{array}{l}\text { LTPA (leisure-time physical activity) at } \\
\text { age } 18-22\end{array}$} \\
\hline Never & 74 & 5.1 & 554 & 29.7 \\
\hline Rarely & 97 & 6.8 & 318 & 17.0 \\
\hline Sometimes & 252 & 17.6 & 380 & 20.4 \\
\hline Frequently & 457 & 31.9 & 351 & 18.8 \\
\hline Always & 554 & 38.6 & 263 & 14.1 \\
\hline \multicolumn{5}{|c|}{$\begin{array}{l}\text { Current LTPA (leisure-time physical } \\
\text { activity) }\end{array}$} \\
\hline Inactive* & 693 & 55.4 & 1084 & 65.5 \\
\hline Insufficiently active ${ }^{* *}$ & 226 & 18.1 & 292 & 17.6 \\
\hline Active*** & 331 & 26.5 & 279 & 16.9 \\
\hline
\end{tabular}

* Participants who reported no LTPA (leisure-time physical activity).

* Participantes que não relataram prática de AFL (atividade física de lazer).

** Participants who practiced LTPA (<600MET/week).

** Participantes que praticaram AFL (<600MET/semana).

*** Participants who practiced LTPA ( $>=600 \mathrm{MET} /$ week).

*** Participantes que praticaram AFL (>=600MET/semana). 
Table 2 - Crude and adjusted odds ratios (OR) and 95\% confidence intervals (95\% Cl) for current leisure-time physical activity according to the frequency at 18-22 years. Pro-Saude Study, 1999-2001.

Tabela 2 - Odds ratios (OR) brutos e ajustados e intervalos de 95\% de confiança (IC 95\%) para atividade física de lazer atual segundo a freqüência de atividade física entre 18 e 22 anos de idade. Estudo Pró-Saúde, 1999-2001.

\begin{tabular}{|c|c|c|c|c|c|c|c|c|}
\hline & \multirow[t]{2}{*}{$\mathrm{N}$} & \multirow{2}{*}{$\begin{array}{c}\text { Inactive } \\
(\%)\end{array}$} & \multicolumn{3}{|c|}{ Insufficiently active } & \multicolumn{3}{|c|}{ Active } \\
\hline & & & $\%$ & $\begin{array}{c}\text { Crude OR } \\
(95 \% \mathrm{Cl})\end{array}$ & $\begin{array}{l}\text { Adjusted OR } \mathrm{R}^{\mathrm{a}, \mathrm{b}} \\
(95 \% \mathrm{Cl})\end{array}$ & $\%$ & $\begin{array}{c}\text { Crude ORa } \\
(95 \% \mathrm{Cl})\end{array}$ & $\begin{array}{c}\text { Adjusted OR }{ }^{\mathrm{a}, \mathrm{b}} \\
(95 \% \mathrm{Cl})\end{array}$ \\
\hline \multicolumn{9}{|l|}{ Females } \\
\hline Never/Rarely & 840 & 68.0 & 18.7 & 1.00 & 1.00 & 13.3 & 1.00 & 1.00 \\
\hline Sometimes & 374 & 64.7 & 15.3 & $\begin{array}{c}0.86 \\
(0.60-1.23)\end{array}$ & $\begin{array}{c}0.69 \\
(0.46-1.05)\end{array}$ & 20.0 & $\begin{array}{c}1.59 \\
(1.12-2.25)\end{array}$ & $\begin{array}{c}1.19 \\
(0.79-1.79)\end{array}$ \\
\hline Frequently/Always & 576 & 60.0 & 17.4 & $\begin{array}{c}1.06 \\
(0.78-1.43)\end{array}$ & $\begin{array}{c}0.84 \\
(0.59-1.19)\end{array}$ & 22.6 & $\begin{array}{c}1.93 \\
(1.42-2.61)\end{array}$ & $\begin{array}{c}1.42 \\
(1.00-2.04)\end{array}$ \\
\hline \multicolumn{9}{|l|}{ Males } \\
\hline Never/Rarely & 172 & 71.2 & 17.1 & 1.00 & 1.00 & 11.7 & 1.00 & 1.00 \\
\hline Sometimes & 250 & 65.0 & 15.7 & $\begin{array}{c}1.00 \\
(0.57-1.78)\end{array}$ & $\begin{array}{c}0.84 \\
(0.43-1.63)\end{array}$ & 19.3 & $\begin{array}{c}1.81 \\
(0.98-3.36)\end{array}$ & $\begin{array}{c}1.42 \\
(0.70-2.89)\end{array}$ \\
\hline Frequently/Always & 987 & 49.7 & 18.2 & $\begin{array}{c}1.52 \\
(0.95-2.44)\end{array}$ & $\begin{array}{c}1.32 \\
(0.77-2.26)\end{array}$ & 32.1 & $\begin{array}{c}3.95 \\
(2.31-6.74)\end{array}$ & $\begin{array}{c}3.33 \\
(1.82-6.10)\end{array}$ \\
\hline
\end{tabular}

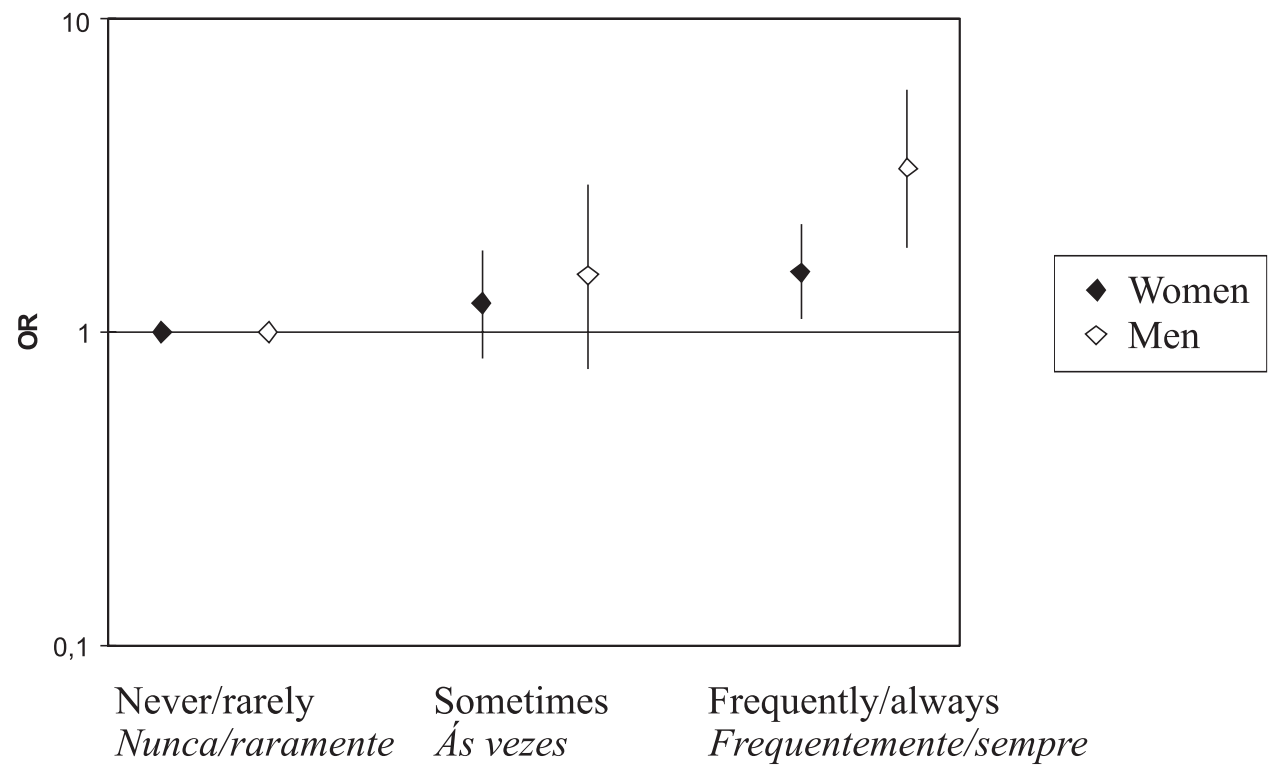

Graph 1 - Adjusted odds ratios (OR) and 95\% confidence intervals (95\% Cl) for being active versus inactive in adulthood, according to the frequency of participation in leisure-time physical activity at age 18-22 years - Pro-Saude Study, 1999-2001.

Gráfico 1 - Odds ratios (OR) ajustados e intervalos de 95\% de confiança (IC 95\%) para participantes ativos versus sedentários na fase adulta, segundo frequência de participação de atividade física de lazer no período de 18 a 22 anos de idade. Estudo Pró-Saúde, 1999-2001. 
rican and Scandinavian populations and suggest that practicing sports at a young age increases the chance of adult physical activity ${ }^{13,17}$ confirming the hypothesis that past behavior is one of the most consistent predictors of present health behavior ${ }^{18}$.

A Finnish longitudinal study showed that the frequency of LTPA during adolescence was greater among boys ${ }^{19}$. Boreham et al. ${ }^{20}$ observed that in Northern Ireland the association between levels of LTPA in adolescence and in early adulthood was low, but was again greater among boys. Tammelin et al. ${ }^{21}$ reported that men who participated in after school sports at least twice a week and women who participated at least once a week at age 14 had greater chances of being physically active or very active as adults, when compared to those who participated in after school sports less than once a week.

Participation in group or team sports appears to predict greater sustainability of LTPA $^{22,23,24}$. Telama et $a l . .^{25}$ believe that the fact that girls participate less in organized sports than boys is one of the reasons that explains this observed difference between genders. Epidemiological evidence, however, seems mixed. A Swedish longitudinal study demonstrated that the level of LTPA at adolescence was associated with the level of LTPA in adulthood in women, but not in men $^{26}$, while in a Canadian longitudinal study there were no gender differences in the maintenance of childhood LTPA into adult life ${ }^{27}$.

Biological and socio-cultural evidence points ${ }^{26,28}$ to possible explanations for gender differences in physical activity practice, but additional studies are needed to clarify the mechanisms of association among these factors and the outcome.

Our study has several limitations. First, quantification of early LPTA was based on participants' recall, which may have led to recall errors, especially among older participants, although our study population was relatively young. Those errors were most likely non-differential, possibly underestimating our association of interest. Second, our question focused only on the frequency of activity, not taking into account the type and duration of physical activity, whereas the regularity of early physical activity might determine later physical activity patterns. Finally, this population is comprised of Brazilian civil servants, which might limit the generalization of our findings.

In conclusion, these data confirm that LTPA at young age promotes active adults. Public policies that encourage LTPA among youth, with specific efforts directed at women, should increase the proportion of physically active adults.

\section{References}

1. Kriska AM \& Caspersen CJ. A collection of physical activity questionnaires for health-related research. Med Sci Sports Exerc 1997; 29(6): S203-5.

2. Barengo NLC, Nissinen A, Tuomilehto J, Pekkarinen H. Twenty-five-year trends in physical activity of 30 - to 59-year-old populations in eastern Finland. Med Sci Sports Exerc 2002; 34 (8): 1302-7.

3. Olshansky SJ, Passaro DJ, Hershow RC, Layden J, Carnes BA, Brody J, Hayflick L, Butler RN, Allison DB, Ludwig DS. Potential Decline in Life Expectancy in the United States in the 21st Century. N Engl J Med 2005; 352(11): 1138-45.

4. Hirvensalo M, Lintunen T, Rantanen T. The continuity of physical activity - a retrospective and prospective study among older people. Scand J Med Sci Sports 2000; 10: 37-41.
5. Leslie E, Fotheringham MJ, Owen N, Bauman. Agerelated differences in physical activity levels of young adults. Med Sci Sports Exerc 2001; 33(2): 255-8.

6. Gordon-Larsen P, Nelson MC, Popkin BM. Longitudinal physical activity and sedentary behavior trends Adolescence to adulthood. Am J Prev Med 2004; 27(4): 277-83.

7. Steptoe A, Wardle J, Fuller R, Holte A, Justo J, Sanderman $\mathrm{R}$, Wichstrom L. Leisure-time physical exercise: prevalence, attitudinal correlates, and behavioral correlates among young Europeans from 21 countries. Prev Med 1997; 26: 845-54.

8. Sallis JF, Prochaska JJ, Taylor WC. A review of correlates of physical activity of children and adolescents. Med Sci Sports Exerc 2000; 32(5): 963-75. 
9. Plotnikoff RC, Mayhew A, Birkett N, Loucaides CA, Fodor G. Age, gender, and urban-rural differences in the correlates of physical activity. Prev Med 2004; 39: 1115-25.

10. Ransdell LB, Vener JM, Sell K. International perspectives: the influence of gender on lifetime physical activity participation. JRSH 2004; 124(12): 12-14.

11. Ainsworth BE, Haskell WL, Whitt MC, Irwin ML, et al. Compendium of physical activities: an update of activity code and MET intensities. Med Sci Sports Exerc 2000; 32(Suppl 9): 498-516.

12. Martinez-Ros MT, Tormob MJ, Pérez-Floresc D, Navarrob C. Actividad física deportiva en una muestra representativa de la población de la Región de Murcia. Gac Sanit 2003; 17(1):11-9.

13. Nelson MC, Gordon-Larsen P, Adair LS, Popkin BM. Adolescent physical activity and Sedentary Behavior: patterning and long-term maintenance. Am J Prev Med 2005; 28(30): 259-66.

14. Brown WJ, Trost SG. Life transitions and changing physical activity patterns in young women. Am J Prev Med 2003; 25(2): 140-3.

15. Pate RR, Pratt M, Blair SN, Haskell WL, Macera CA, Bouchard C, et al. Physical activity and public health: a recommendation from the Centers for Disease Control and the American College of Sports Medicine. JAMA 1995; 273: 402-7.

16. Hallal, PC.; Victora, CG; Azevedo, MR; Wells, JCK. Adolescent Physical Activity and Health - A Systematic Review. Sports Med 2006; 36 (12): 1019-30.

17. Kraut A, Melamed S, Gofer D, Froom P. Effect of school age sports on leisure time physical activity in adults: The Cordis Study. Med Sci Sports Exerc 2003; 35(12): 2038-42.

18. Evenson KR, Wilcox S, Pettinger M, Brunner R, King AC, Mctiernan A. Vigorous leisure activity through women's adult life - The women's health initiative observational cohort study. Am J Epidemiol 2002; 156(10): 945-53.

19. Aarnio M. Leisure-time physical activity in late adolescence. J Sports Sci \& Med. 2003; Suppl.2: 1-41.
20. Boreham C, Robson PJ, Gallagher AM, Cran GW, Savage JM, Murray LJ. Tracking of physical activity, fitness, body composition and diet from adolescence to young adulthood: The Young Hearts Project, Northern Ireland International. J Behav Nutr Phys Act 2004, 1:14.

21. Tammelin T, Näyhä S, Hills AP, Järvelin M. Adolescent participation in sports and adult physical activity. $\mathrm{Am} \mathrm{J}$ Prev Med 2003; 24(1): 22-8.

22. Committee on Sports Medicine and Fitness and Committee on School Health. Organized Sports for Children and Preadolescents. Pediatrics 2001;107: 145962 .

23. Pitsavos C, Panagiotakos DB, Lentzas Y, Stefanadis C. Epidemiology of leisure-time physical activity in sociodemographic, lifestyle and psychological characteristics of men and women in Greece: the ATTICA Study. BMC Public Health 2005; 5:37.

24. Taylor WC, Blair SN, Cummings SS, Wun CC. Childhood and adolescent physical activity patterns and adult physical activity. Med Sci Sports Exerc 1999; 31(1): 11823.

25. Telama R, Yang X, Viikari J, Välimäki I, Wanne O. Physical activity from childhood to adulthood - a 21-year tracking study. Am J Prev Med 2005; 28(3): 267-73.

26. Glenmark B, Hedberg G, Janssons E. Prediction of physical activity level in adulthood by physical characteristics, physical performance and physical activity in adolescence: an 11-year follow-up study. Eur J Appl Physiol 1994; 69: 530-8.

27. Trudeau F, Laurencelle L, Shephard RJ. Tracking of Physical Activity from Childhood to Adulthood. Med Sci Sports Exerc 2004; 36(11): 1937-41.

28. Beunen GP, Lefevre J, Philippaerts RM, Delvaux K, Thomis M, Claessens AL, Vanreusel B, Lysens R, Eynde BV, Renson R. Adolescent Correlates of Adult Physical Activity: A 26-year Follow-up. Med Sci Sports Exerc 2004; 36(11): 1930-6.

Recebido em: 02/09/08 Versão final reapresentada em: 14/11/08 Aprovado em: 17/12/08 